\title{
Testing the Flexibility of Pancasila as an Open Ideology in the Synergy of Designing the Law Enforcement Reform
}

\author{
Wahyu Beny Mukti Setiyawan ${ }^{1}$, I Gusti Ayu Ketut Rachmi Handayani ${ }^{2}$, Muhammad Rustamaji ${ }^{3}$ \\ ${ }^{1.2 .3}$ Universitas Sebelas Maret \\ Surakarta, Indonesia \\ wahyubeny@student.uns.ac.id
}

\begin{abstract}
The problem statements answered in this study are: (i) why synergy is needed in designing law enforcement reforms; and (ii) how are the parameters of the flexibility limit of Pancasila in synergizing the design of law enforcement reforms. Nowadays, it is found that the implementation of law do not fit the proportions, creates a level of controversy that is dominated by the proportion between cases of low class society people who are not handled equally with big cases. This has become a problem in the law enforcement in Indonesia which, when explored, raises the question, that, is it necessary to reform law enforcement. Indeed, law enforcement must be more than just the realm of the apparatus, the synergy of law-making and its implications in the society is another dogma that must receive attention. This article is normative conducted by using primary and secondary legal materials, analyzed deductively with a case approach and philosophicalconceptual approach. The results of the study indicate: (i) synergies in designing the law enforcement reform are needed because: $a$. The need for law enforcement parameters based on Pancasila, b. Judicial failure to implement the law enforcement; and (ii) the parameters of the flexibility limit of Pancasila in the synergy in designing the law enforcement reforms: a. parameters of God and humanity as a moral basis, b. parameters of unity and democracy as the basis of policy, c. parameters of social justice as the basis for the goals to be achieved.
\end{abstract}

Keywords- Law Enforcement, Pancasila, Reform.

\section{INTRODUCTION}

Law enforcement in Indonesia has its own complexities, as law reform which has its challenges. When viewed by naked eye and through a general perspective, law enforcement in Indonesia still shows several weaknesses. In this case, it is necessary to explore the factors that cause these weaknesses. Therefore, the problem of law enforcement in Indonesia always dominates the news because the public spotlight is already skeptical, pessimistic and apathetic about one of the implementations of the rule of law. Several cases of concern also meet the current of criticism of the law enforcement process in Indonesia, particularly in the current era of information disclosure. As a result, negative news about the law enforcement process becomes additional material for the media that is packaged in provocative news and ironically this situation is true.
Conceptually, the essence of the meaning of law enforcement lies in the activity of harmonizing the relationship of values outlined in the rules as a series of final value translations, to create, preserve and maintain social peace [1].

The problem that occurs today is the phenomenon that the realm of law enforcement, particularly in the field of criminal justice, has decreased in effectiveness when viewed from various perspectives. Criminal justice is actually seen as a parameter of the success or failure of the state in upholding the rule of law (supremacy of law) as one of the characteristics of the rule of law. [2] [3]. The dimension of discussion regarding the criminal justice cannot be separated from the implementation of law enforcement. This happened since contextually, law enforcement is explicitly contained in the criminal justice process. Meanwhile, in the criminal justice process, the origin or upstream is the criminal procedural law or the formal criminal law, which is referred to as jus puniendi, which is the right of the state to prosecute a crime, the right to impose a crime and the right to carry out a crime [4]. Thus, the failure to prove the effectiveness of criminal justice is the basis for a strong argument that shows the weakness of the realm of law enforcement. In fact, the judiciary must be placed on the human side that puts forward the values of justice (fairness) while maintaining the value of purposiveness and legal certainty. In order to realize a humanistic criminal justice, it is absolutely necessary to have the wisdom of law enforcement officers [5]. The constellation of problems also continues to grow along with the changing times and the changes in society. Ironically, the legal changes tend to be slow and are still demanded through the existence of courts that can accommodate justice, benefit and certainty in it.

The problems above open the door to re-exploring the values of Pancasila since the law enforcement is critical and tends to require improvements. In its position, as a legal ideology, the value (virtue) of Pancasila must be grounded or incarnated into all legal rules in Indonesia. This can be done by filtering the legal rules that will be made. It is expected that the rule of law can be a bridge for the values of Divinity, Humanity, Unity, Democracy and Social Justice, so that Pancasila is attached as a legal 
ideology from the philosophical level to the practical level of its implementation.

\section{RESEARCH METHOD}

This article included in the normative legal research conducted by using primary legal materials and secondary legal materials. Furthermore, it was analyzed deductively with a case approach and a philosophical-conceptual approach. The nature of the research was classified as descriptive, analytical and diagnostic by looking at the problems related to the law enforcement and then giving a solution in the form of the parameters of the Pancasila flexibility limit in synergistically designing the law enforcement reforms.

\section{FINDINGS AND DISCUSSION}

\section{The Urgency of Synergy in Designing Law Enforcement Reforms}

First, the need for law enforcement parameters based on Pancasila. The existence of Pancasila is a philosophical foundation, including in the development of Indonesian law. Previously, there was confusion in interpreting and positioning Pancasila, which is more precisely as the ideology of the state or the source of all sources of law. This question is answered in the Preambule of the 1945 Constitution of the Republic of Indonesia as the standard cause for the direction of the nation's goals which in achieving the nation's ideals (rechtsidie) are outlined and guarded by Pancasila. This gives the exclusive side of Pancasila not as a state ideology in a narrow sense, but also includes the source of the development of Indonesian state law on a meta-norm scale or above all norms that are axioms or whose existence does not need to be questioned. Therefore, it is more appropriate to classify Indonesia as a legal state with Pancasila insight [6]. Pancasila is a clarificative basis to be a reference in building reform of law enforcement so that it is in accordance with the idiom and nature of the values of Pancasila.

The reflection of Pancasila in designing the law enforcement reform is the first step to match and harmonize the fabric of values between Pancasila and the law. Pancasila functions as a ratio-legis or basis for the formation and justification of all legal norms in the context of running the state [7]. The harmony, relevance and conformable of the fabric of Pancasila values and the law are expected to be able to realize the rules that become the reference for the law enforcement process so that they have the character of Pancasila. The urgency is to carry out the full development of national law with Pancasila as the main catalyst so that it does not originate or minimize the adoption of foreign legal products, which is clearly a simulacra effect. Simulacra is the tendency to inject elements from a foreign legal system into the original legal system of one's own country. This is driven by the stigma that foreign law influences are better and more complex in solving problems Simulacra adalah kecenderungan melakukan injeksi unsur dari sistem hukum asing [8]. Problems, particularly the irrelevantness of foreign legal products in the character of Indonesian law enforcement, for example the rules of criminal law which often clash with social catalysts.

Pancasila in its position is also the basic norm which in that position becomes the basic norm for the Indonesian legal system [9], including in the realm of law enforcement. Such meaning is identified with the term from Hans Kelsen, namely Grundnorm. In its development, the definition was reclassified into two elements, namely "Grundnorm's position" and "Grundnorm's role" [10]. Regarding the Grundnorm position, Kelsen takes this basic norm as the initial premise. Grundnorm is assumed to be the basis from which everything started, not derived from anywhere, its validity is also taken for granted. It is valid since it is presupposed to be valid [10]. Grundnorm is the basis without having to be adapted to other norms. Therefore, Grundnorm transcends the positive legal order which is transcendental-logic which is above positive law [9]. Pancasila becomes an axiomatic meta-norm that does not require any further reference to its existence. Consequently, Pancasila is always located at the top of the pyramid hierarchy of legal order, therefore it must be the spirit of the existing legal order. This consequence also refers to the position of Pancasila as the state philosophy. Philosophy is the embodiment of the wishes of the people, identical with the wishes and character of the nation [11]. The position of Pancasila as a legal ideology related to law enforcement means that from a philosophical, theoretical to dogmatic level, it must involve the values of Pancasila to form a law enforcement perspective with Pancasila insight. The process of direct law enforcement has become a domain that must open up space for Pancasila insight to be able to merge and guide it as a legal ideology, particularly towards the injection of Pancasila values as an open legal ideology.

The description above is relevant to Savigny's thinking who constructs his theory about the existence of an organic relationship between law and the nature or character of a nation [12]. The true law is not made but must be found in the soul of the people or the soul of the nation (volkgeist). Therefore, the problem of managing the law is not artificially forming principles and doctrines, but finding principles and doctrines in living the legal values by exploring the core of the soul of the people [12]. This is also driven by the assumption that foreign (western) law is more modern and advanced than customary law, which has weakened our thoughts and attitudes to respect the cultural values of this nation, namely Pancasila. Pancasila as the cultural value of the nation and the philosophy of life of the Indonesian nation has been eliminated by the materialism philosophy of life which is the influence of the ideology of globalization 
which is very rapid today[13]. This corresponds to the socalled simularca kondisi condition [8]. Therefore, there is a need for a balance between the desire to form the legal reforms through the statutory regulations while still paying attention to the realities that live in the society. The reality that lives in this society is called the living law which is a reflection of the inner order of society in the form of values in that society [14]. Therefore, in terms of making a rule of law so that it can run effectively, it is necessary to pay attention to the law that lives in the community.

Second, judicial failure to implement the law enforcement. In this case, the failure of the judiciary in implementing the law enforcement must be viewed from 3 (three) main factors, namely: (i) the substance of the regulation; (ii) implementing apparatus; and (iii) community legitimacy in accepting its implementation [15]. The factor of the substance of the regulation, dealing with problems such as rules that are no longer in accordance with the development of society as well as weaknesses in terms of the existence of optional articles provided by law. This limits the courts in formulating a truly fair decision. Law enforcement in the realm of criminal law, for example, still refers to the Criminal Code (KUHP) which still contains the perspective of the colonial era and its existence in the Indonesian legal system is mandated to remain in effect as the Transitional Provisions of Article II of the Constitution of the Republic of Indonesia Year 1945 [16]. Furthermore, the Criminal Code is given a legal birth certificate number, particularly Law Number 1 of 1946 concerning Criminal Law Regulations and is increasingly being strengthened by Law Number 73 of 1958 concerning Declaring the Enforcement of Law Number 1 of 1946 concerning Criminal Law Regulations for All Territory of the Republic of Indonesia and Amend the Criminal Code. This situation locks up changes, exacerbated by the lack of willingness to change the substance of the law.

The facts above are a contributing factor to the delay in the law enforcement due to the different perspectives of giving punishment. The Criminal Code still prioritizes the classical criminal flow [17]. by making the provision of punishment as a gift of sorrow [18]. This of course has been reduced and marginalized by disruption where legal thought puts forward the fulfillment of Human Rights (HAM) in the current era. With the paradigm that has changed, it is time to make changes to the mindset of giving punishment as misery. The development of human values and Human Rights (HAM) has become the embryo of change towards a more humane punishment and protects the interests of all parties. This is attempted by starting from the realization of law enforcement which does require changes. These changes, including the pursuit of a dignified criminal justice, will be fraught with various and extraordinary obstacles. In the development of criminal law throughout the world, it is faced with the fact that there has never been the formation of an 'original' criminal law created by a particular society. The Dutch Criminal Code, for example, still inherits the rules from the French Criminal Code. The draft Criminal Code, which is projected as the result of the great work of the Indonesian people, also basically has similarities with the current Criminal Code. However, it should be borne in mind that in the process and efforts to reform the national criminal law, forms of political intervention need to be avoided and must remain focused on the interests of developing a more systematic national law and internalizing the principles of protecting human rights and civil liberties.

The next problem that is classified is law enforcement officials who are also filled with protracted pressure from the fact that there are still many corruption cases involved. In the data obtained from the records (Indonesian Corruption Watch (ICW) conducted from March 2012 to November 2018, this period shows that at least 28 judges and court officials in Indonesia have been involved in corruption cases [19]. This shows that resistance from the involvement of law enforcement officers, particularly as the problem that will be the focus of this dissertation proposal, namely the judiciary apparatus, is a central point that can weaken the effectiveness of criminal justice in Indonesia. In a crossliterature study, there is a very strong adage in the law enforcement scene in Indonesia. This adage is the prima donna and is given to be introduced during the professional education of the Prosecutor and the Education of Judges, as if it is an encouragement for prospective Prosecutors or Judges to be able to reflect on it later in the honorable stage. The adage comes from the statement of Bernardus Maria Taverne (1874-1944): "Give me good judges, prosecutors, policemen and advocates, I will surely eradicate crime even without a law" [20]. The statement from B. M Taverne can be studied, namely the word give it shows that in the law enforcement it is not from the side of the law that determines, however, it is strongly influenced and determined by the human factor. The dynamics of law enforcement in Indonesia shows the truth of Taverne's statement. The diversity of law enforcement in Indonesia is largely determined by the commitment and figures of individuals who become police, prosecutors, judges and advocates.

\section{The Parameters of the Flexibility Limit of Pancasila in the Synergy in Designing the Law Enforcement Reforms}

First, parameters of divinity and humanity as moral basis. The precepts of God and humanity serve as the basis of morality, which means that the whole process of law enforcement must prioritize morality where the community also sees the process. Pancasila contains the essence of the nation's morality which with its position as a legal ideology, the morality of the nation will also become the legal morality that permeates the spirit of the 
Indonesian legal system. The use of Pancasila can place the law more precisely as the main validity that is in line with morals. In other words, morals become a guiding corridor for the law that is implemented by the legal subjects. Moral is a human guide in every activity of their life, which gives to the truth according to ratio. Aristotle explained that the essence of human being is rational moral, which views truth (theoria, contemplation) as the virtue of life (summum bonum). In the process, humans are guided by reason and morals [21]. The moral foundation concerned is the embodiment of the precepts of the One Godhead in the form that the law enforcement apparatus in Indonesia must focus on moral responsibility to God Almighty. Law basically has a relationship with morality, as Hart's opinion reflects the influence of morality on law (the influence of morality on Law). The laws of every modern state represent thousands of points full of morality accepted by society as well as broader moral ideas. This influence then penetrates the law in real terms and is followed by the embodiment of the human values that underlie that law enforcement must pay attention to the side of humanism so that it can be said to have dignity.

In the parameters of humanity in the Fair and Civilized Precepts of Humanity, it also emphasizes human dignity and worth. Humans were created by God Almighty with a set of rights that guarantee their status as humans which are summarized in Human Rights. In this case, the position as a state of law (rechtstaat) is recognized as a regulatory framework to guarantee human rights in the form of guaranteeing the interests of justice for all people. Everyone has the right to get justice. Thus, the developed state of law is not absolute rechtsstaat but democratische rechtsstaat [22]. Thus, many things show how the law reflects morality. This is a fact, which means that the stability of the legal system depends in part on its conformity with morals and its existence must be recognized [23], including stability in the law enforcement arena which must be in accordance with the moral values of Pancasila. The Divine Parameter mandates that there should be no national legal product that is contrary to religion that is rejecting or hostile to religion. Meanwhile, the principle of humanity binds law enforcement which has a humanist side [24]. The output generated from the parameters of God and humanity as a moral limit in the law enforcement is the existence of ethical values as a guide for the entire law enforcement process. In this case, the law enforcement officials must adopt these ethical values. Thus, the law enforcement process is expected to have moral accountability and can be personally accountable to God for its users. The implication is that it is expected to be able to create a law enforcement process that has a religious philosophy and has preventive means within its internal users. Therefore, the law enforcement is not arbitrary since it is accountable to God as a means of correction as well as a reminder within the law enforcement apparatus. It is expected that law enforcement will also become more humane by prioritizing the guarantee of human rights in the process. This is also in line with the precepts of Divinity and the precepts of Humanity as based on the morality of a nation or the basis of morality of a nation. Thus, it is expected that the moral law enforcement can be produced to guard towards the general welfare.

Second, parameters of unity and democracy as policy basis. The next parameter lies in the Precepts of Humanity, the Precepts of Unity and the Precepts of Policy which must be positioned as the basis of the policy (wisdom). Therefore, in the law enforcement process, public participation in the form of control and disclosure of information fulfills the cause as the fulfillment of just and civilized human precepts with a fair feeling of participating in the law enforcement process. The implication is that the process and results of the law enforcement can gain legitimacy from the community. Roeslan Saleh views the position of Pancasila in the Preamble to the 1945 Constitution of the Republic of Indonesia in terms of its elaboration or translation into legal products as a general legal ideology towards the Indonesian Legal Order, which is a reflection of values, ideals of humanity and social justice with religious character of each legislation [23]. The parameter of entity and unity or nationality mandates that Indonesian law must be a national law that applies to all Indonesian people [24]. Meanwhile, the parameters of democracy or populist mandate that in the relationship between law and power, power must be subject to the law, power belongs to the people and people's representatives. Thus, the law enforcement process must also reflect the value of unity and integrity. In this paradigm, law enforcement officials must still be guided by the public interest. As in the rules of making rules, it must not conflict with the public interest, not against the norms in the society, so that it can create law enforcement products that have the power of conduct and have legitimacy in the form of recognition from the community itself. The fulfillment of the public interest is in line with the beginning of realizing the general welfare.

Third, social justice parameters as the basis for welfare goals to be achieved. The next parameter is obtained from the Precepts of Social Justice which is a form of target that will be aimed at law enforcement based on morality and prioritizing processes that involve community participation. Thus, it is expected that the existence of control in the form of community involvement in the law enforcement process can produce the rule of law that is truly in harmony with the concept of the legal ideology of Pancasila. The parameters of social justice mandate that all citizens have the same rights and that everyone is equal before the law [24]. The law enforcement process is required to maintain the stability of the government in carrying out its function as a protector of the community by reflecting the obedience referred to as the embodiment of people's democratic values. Democracy adopted in Indonesia is a democracy 
based on Pancasila. Thus, Indonesian democracy implies that aside from general values, special values are required. Indonesian democracy is democracy led by wisdom in representative deliberation. In this case, the government must uphold the conception of the people, by the people and for the people. This includes maintaining the stability of law enforcement which is built on trust and social legitimacy of the community. Thus, the process of law enforcement as a form of state guarantee against the rule of law, must be able to be transformed as a reinforcement of this populist-based democracy. In its development, law enforcement can be equipped with community control mechanisms by increasing community participation as the owner of the social legitimacy. The social justice contained in Pancasila becomes a philosophical, ideological and state guideline to accommodate the phrases of justice and expediency in addition to legal certainty. Therefore, aside from fulfilling the legal certainty, in the practice, the administration of the state needs to be accommodated as well as the fulfillment of the values of justice and benefits so that they are in line with the basic legal values which are the objectives of the law itself. In the form of social justice as the ultimate goal of the law enforcement, it is realized by consistently implementing the principle of equality before the law. It is expected that this equality can provide justice in the scope and form of legal protection for the community and justice seekers. In the perspective of Pancasila, the principle of equity in correcting and realizing social justice rests on the values or philosophy of Pancasila. Thus, the law enforcement process must not violate human rights and must provide a balance between the interests of the state which represent the public interest (society) and individuals.

\section{IV.CONCLUSION}

The conclusions of this article are as follows: (i) the urgency of synergy in designing the law enforcement reform is based on the need for the law enforcement parameters based on Pancasila and the failure of the judiciary to implement the law enforcement; and (ii) the parameters of the flexibility limit of Pancasila in the synergy in designing the law enforcement reforms include the parameters of God and Humanity as the moral basis, the parameters of Unity and Democracy as the basis for policies and the parameters of Social Justice as the basis for the welfare goals to be achieved.

\section{REFERENCES}

[1] Soerjono Soekanto, Factors Affecting the Law Enforcement, Raja Jakarta, Grafindo Persada, 1993

[2] E. S. C. Wade and G. Geofrey, Constitutional Law: An Outline of The Law and Practice of The Citizen and the Including Central and Local Government, the Citizen and the State and Administrative Law, 7Th Edition, London, Longmans, 1965.

[3] C. Anwar, Constitutional Theory and Law, Malang, Setara Press, 2011.
[4] Andi Hamzah, Principles of Criminal Law in Indonesia \& Its Development, Jakarta, PT. Sofmedia, 2011.

[5] Ibnu Artadi, "Claiming the Effectiveness of Implementing Short Imprisonment, Towards a Humane Criminal Justice Process", "Pro Justitia, vol. 24, no. 4, pp. 376-386, October 2006.

[6] Anthon F. Susanto, Legal Semiotics, Text Deconstruction Towards Meaning Progressivity, Bandung, Refika Aditama, 2019.

[7] Abu Bakar Busro, Values and Its Various Aspects in Law, An Introduction to the Study of Philosophy of Law, Jakarta, Bhratara Media Niaga, 1989.

[8] Anthon F. Susanto, Transformative-Participatory Legal Research,, Malang, Setara Press, 2015.

[9] Bernard L. Tanya, et. al., Pancasila Frame Indonesian Law, First Printing, Yogyakarta, Genta Publishing, 2014.

[10]Hans Kelsen, General Theory of Law and State, New York, Russel \& Russel, 1961.

[11] Ni'matul Huda, Indonesian Constitutional Law, Revised Edition, Jakarta, Rajawali Press, 2005.

[12] Bernard L. Tanya, et. al., Legal Theory of Orderly Strategies of Man across Spaces and Generations, Yogyakarta, Genta Publishing, 2010.

[13]Romli Atmasasmita, "Understanding Integrative Legal Theory"," Legality, vol. 3, no. 2, pp. 14-28, December 2012.

[14] Khopiatuziadah, "Public Participation in the Formation of Laws: A Foothold of Sociological Thinking as a Foundation for Thinking in the Preparation of Academic Manuscripts"," Indonesian Legislation Journal, vol. 10, no. 1, pp. 1-14, March 2013.

[15]Lawrence M. Friedman, The Legal System: A Social Science Perspective, New York, Russel Sage Foundation, 1975.

[16] Sudarto, Law and Criminal Law, Bandung, Alumni, 1977.

[17] Muladi and Barda Nawawi Arief, Criminal and Sentencing, Semarang, Lecture Materials Provider Agency FH UNDIP, 1984.

[18]Johan Andenaes, Punishment and Deterrence, Michigan, The University of Michigan Press, 1974.

[19]F. Ferdiansyah, "Pikiran Rakyat.com," 3011 2018. [Online]. Available: https://www.pikiran-rakyat.com/nasional/pr01303993/28-aparat-pengadilan-tersandung-kasus-korupsi-433881. [Accessed 25 2021]

[20]Zamroni, et. al., Collection of Essays on Legal Perspectives in Indonesia, Bogor, Elaku, 2020.

[21]Bernard L. Tanya, Law Enforcement in the Light of Ethics, Yogyakarta, Genta Publishing, 2011.

[22] Mohammad Sinal, Pancasila Consensus of the Indonesian Nations, Malang, Madani, 2017.

[23]M. Ali Safa'at, Legal Concepts H. L. A Hart, Jakarta, Constitution Press, 2016.

[24] Mochtar Kusumaatmaja, Legal Concepts in the Development, Bandung, Alumni, 2006. 